NBER WORKING PAPER SERIES

\title{
THE INFLUENCE OF IRVING FISHER ON MILTON FRIEDMAN'S MONETARY ECONOMICS
}

\author{
Michael D. Bordo \\ Hugh Rockoff \\ Working Paper 17267 \\ http://www.nber.org/papers/w17267
}
NATIONAL BUREAU OF ECONOMIC RESEARCH
1050 Massachusetts Avenue
Cambridge, MA 02138

August 2011

There were no outside sources of funding for this paper. The views expressed herein are those of the authors and do not necessarily reflect the views of the National Bureau of Economic Research.

NBER working papers are circulated for discussion and comment purposes. They have not been peerreviewed or been subject to the review by the NBER Board of Directors that accompanies official NBER publications.

(C) 2011 by Michael D. Bordo and Hugh Rockoff. All rights reserved. Short sections of text, not to exceed two paragraphs, may be quoted without explicit permission provided that full credit, including (C) notice, is given to the source. 
The Influence of Irving Fisher on Milton Friedman's Monetary Economics

Michael D. Bordo and Hugh Rockoff

NBER Working Paper No. 17267

August 2011

JEL No. B21,B31,N10

\begin{abstract}
$\underline{\text { ABSTRACT }}$
This paper examines the influence of Irving Fisher's writings on Milton Friedman's work in monetary economics. We focus first on Fisher's influences in monetary theory (the quantity theory of money, the Fisher effect, Gibson's Paradox, the monetary theory of business cycles, and the Phillips Curve, and empirics, e.g. distributed lags.). Then we discuss Fisher and Friedman's views on monetary policy and various schemes for monetary reform (the $\mathrm{k} \%$ rule, freezing the monetary base, the compensated dollar, a mandate for price stability, 100\% reserve money, and stamped money.) Assessing the influence of an earlier economist's writings on that of later scholars is a challenge. As a science progresses the views of its earlier pioneers are absorbed in the weltanschauung. Fisher's Purchasing Power of Money as well as the work of Pigou and Marshall were the basic building blocks for later students of monetary economics. Thus, the Chicago School of the 1930s absorbed Fisher's approach, and Friedman learned from them. However, in some salient aspects of Friedman's work we can clearly detect a major direct influence of Fisher's writings on Friedman's. Thus, for example with the buildup of inflation in the 1960s Friedman adopted the Fisher effect and Fisher's empirical approach to inflationary expectations into his analysis. Thus, Fisher's influence on Friedman was both indirect through the Chicago School and direct. Regardless of the weight attached to the two influences, Fisher' impact on Friedman was profound.
\end{abstract}

Michael D. Bordo

Department of Economics

Rutgers University

New Jersey Hall

75 Hamilton Street

New Brunswick, NJ 08901

and NBER

bordo@econ.rutgers.edu

Hugh Rockoff

Department of Economics

75 Hamilton Street

Rutgers University

College Avenue Campus

New Brunswick, NJ 08901-1248

and NBER

rockoff@fas-econ.rutgers.edu 


\section{Introduction ${ }^{1}$}

Irving Fisher was the most prominent American economist of the early twentieth century. Milton Friedman was the most prominent economist of the later twentieth century. Fisher's writings in monetary economics, especially the Purchasing Power of Money (1911) had a major impact on Friedman's theoretical and empirical work in monetary economics. In addition, Fisher's views on monetary policy and monetary reform aligned quite clearly with Friedman's views.

This paper examines the influence of Fisher's writings on Friedman's work in monetary economics. We focus first on Fisher's influences in monetary theory ( the quantity theory of money, the Fisher effect, Gibson's Paradox, the monetary theory of business cycles and the Phillips Curve), empirics (eg distributed lags.). Then we discuss Fisher and Friedman's views on monetary policy and various schemes for monetary reform ( the $\mathrm{k} \%$ rule, freezing the monetary base, the compensated dollar, a mandate for price stability, 100\% reserve money, stamped money.) Section 2 provides a brief biography of the two scholars and brings out some of the similarities of their careers. Section 3 discusses Fisher's influence on Friedman's monetary theory. Section 4 discusses Fisher and Friedman on monetary reform. To clarify Fisher’s influences on Friedman we document all the citations to Fisher in Friedman's published work in Table 1. In section 5 we conclude with some insights on Fisher's contribution to the evolution of Friedman's thinking.

\footnotetext{
${ }^{1}$ We thank Allan Meltzer, Robert Hetzel, and the participants in a session on Irving Fisher and Modern Economics at the American Economic Association Meetings in January 2010 organized by Robert Dimand for comments on an earlier draft. We are responsible for the remaining errors.
} 


\subsection{Irving Fisher}

Irving Fisher (1867 -1947) had a long, distinguished, and amazingly varied academic and business career. Fisher, the son of a Congregationalist minister, was born in Saugerties New York. He was an undergraduate and graduate at Yale, and spent most of his academic career at Yale first in the Department of Mathematics, then in the Department of Political and Social Science, and finally in the Department of Economics. He served as president of the American Economic Association in 1918 and as the first president of the Econometrics Society in 1931-33.

Fisher's academic contributions, many of which we discuss below, spanned a remarkably wide range. Fisher's major works in economics, many of which are still read and cited include "Appreciation and Interest" (1896), The Purchasing Power of Money (1911), Stabilizing the Dollar (1920), The Rate of Interest (1930), and the Debt-deflation Theory of Great Depressions (1933).

Fisher was also deeply committed to spreading the gospel of healthful living. One of his bestselling books, which ran through many editions, was How to Live. Fisher was also a strong supporter of Prohibition. His book Prohibition at its Worst (1926a) made the case for Prohibition in part by claiming that it raised productivity. Fisher even made a counterfactual calculation purporting to show how much national income had been increased through the adoption of prohibition. An inveterate inventor, one of his inventions, a system for manipulating index cards, made him a fortune. Fisher formed the Index Visible Company to market the invention and in the 1920s it was merged into the company that became Sperry Rand. The fortune however, didn't last long; he lost it in the stock market crash of 1929. 


\subsection{Milton Friedman}

Milton Friedman (1912 - 2006) had a long and distinguished career spanning the last six decades of the twentieth century. Friedman was an undergraduate at Rutgers University in the early 1930s where he studied under Arthur Burns and Homer Jones. He did his graduate work at the University of Chicago where Frank Knight, Henry Simons and Jacob Viner trained him in the Chicago tradition of classical economics. He also studied at Columbia under the mathematical economist and statistician Harold Hotelling and the institutional and empirical economists Wesley Clair Mitchell and John Bates Clark. Friedman spent most of his academic career at the University of Chicago. After retiring from Chicago in 1977 Friedman moved to the Hoover Institution at Stanford University for the rest of his life.

Friedman is known for his path breaking work in methodology, economic statistics, price theory, the consumption function and monetary economics. He was a champion of the modern quantity theory of money and was a founder (along with Karl Brunner and Allan Meltzer) of the monetarist school that successfully opposed itself against the dominant Keynesian paradigm of the post World War II era. In three monumental books ( A Monetary History of the United States 1963, Monetary Statistics of the United States 1970 and Monetary Trends in the United States and United Kingdom 1982) as well as numerous articles, Friedman and his collaborator Anna Jacobson Schwartz provided overwhelming evidence on the influence of the quantity of money secularly on the price level and on real income over the business cycle. In this work and elsewhere Friedman documented the failures of discretionary monetary policy by the Federal Reserve from its founding and made the case for rules over discretion. For his scientific research in economics Friedman was awarded the Nobel Prize in Economics in 1976. 
Like Irving Fisher, Milton Friedman developed several proposals for monetary reform. Friedman long championed the case against discretionary monetary and fiscal policy made by Henry Simons and Lloyd Mints, two of his predecessors at the University of Chicago. Over the years Friedman devised several rules for policy formulation which have reflected his developing views on money and the economy. The first rule (1948) would maintain full employment by offsetting negative (positive) departures by money financed budget deficits ( and surpluses). The second (1960) would have monetary authorities preserve price stability by expanding the money supply at a steady and known rate sufficient to finance the growth of real output allowing for a trend in velocity. A 1982 revision to that rule would have monetary authorities freeze the monetary base. To provide an efficient set of monetary arrangements ( the optimum quantity of money), the rule would set the rate of deflation equal to the real interest rate, or alternatively would pay interest on bank reserves and allow competing banks to pay interest on all deposits. Friedman (1960) also agreed with Simons (1936) on the case for 100\% reserve banking and in 1953 made a strong case for flexible exchange rates to govern the economic relationship between nation-states and against a return to the gold standard (1962b).

Finally, like Fisher, Friedman was a strong practitioner of normative economics. For over four decades he acted as the leading American advocate of the classical liberal order-free markets and free speech. His 1962 work Capitalism and Freedom made a strong case for limited government intervention in the economy. To address social ills he proposed schemes based on free market solutions: tuition vouchers to improve education, a negative income tax to help low income families and the abolition of conscription. 


\subsection{Parallel Careers}

Milton Friedman called Fisher "the greatest economist the United States has ever produced" (Friedman 1994, 37). We suspect that Fisher would have admired Friedman as well. After all, their careers share some remarkable parallels. Early in their careers both Fisher and Friedman made important contributions to pure theory. Fisher published The Nature of Capital and Income in 1906 and Friedman with the statistician Leonard Savage published papers on utility and risk (Friedman 1948, 1952). Both Fisher and Friedman went on, of course, to make lasting contributions, to monetary economics. Fisher's masterpiece was The Purchasing Power of Money (1911) and Friedman's, written with Anna J. Schwartz, was A Monetary History of the United States (1963). Both books use the quantity theory of money as their basic organizing principle. Both books attempt to estimate the quantity theory empirically and to do that both authors assembled new data on monetary aggregates. Both Fisher and Friedman, moreover, made theoretical advances in the construction of index numbers as an outgrowth of their attempts to assemble data with which to test the quantity theory: Fisher (1922) analyzed alternative formulas for computing price indexes and Friedman (1962a) analyzed alternative methods for filling gaps in economic time series. Both books relied heavily on economic history to test the quantity theory.

Both Fisher and Friedman were inveterate reformers who dedicated themselves to improving the world by crafting elegant reforms and then attempting to persuade the public of their validity. It is not surprising that they would both advocate reforms of the monetary system based on their studies of monetary history. But the range of reforms championed by both Fisher and Friedman as indicated by the following table is truly astonishing. 


\begin{tabular}{|l|l|}
\hline \multicolumn{2}{|c|}{ Reforms championed by Fisher and Friedman } \\
\hline Fisher & Friedman \\
\hline Compensated dollar & A monetary growth rule \\
Price level stability rule & $100 \%$ Reserves \\
100\% Reserves & Balancing the Budget over the Business Cycle \\
Stamped Money & Negative income tax \\
Prohibition & All-volunteer army \\
Vegetarianism & School Vouchers \\
Government funded medical care & Fedical Insurance vouchers \\
\hline
\end{tabular}


Even a brief comparison of the two cannot be complete without noting that the reputation of both men suffered for a time because of predictions that went badly wrong. Fisher's bad prediction has become legendary. During the 1920s Fisher's opinions about the stock market were reported regularly in the papers. Fisher computed his own stock market indexes and the New York Times regularly reported their movements. But on October 15,1929, the Times reported that Fisher had told a meeting of the Purchasing Agent Association that stocks had reached "what looks like a permanently high plateau." the Times went on to report that

"While the tone of his address proper reflected a moderate optimism, in the informal questioning which followed Professor Fisher fell into almost unqualified optimism. In reply to one question, he declared that he expected "to see the stock market a good deal higher than it is today, within a few months"' (New York Times, Oct 16, 1929, 8.)

Black Thursday was October 24, 1929. Fisher had made his optimistic prediction only weeks before the start of the most disastrous stock market decline in history.

Friedman's fall from grace came in the early 1980s. As Edward Nelson (2007) explains in his careful study of Friedman's post-1963 discussions of monetary policy, Friedman made inaccurate predictions of prices and the level of economic activity.

"... from 1982 to 1985, Friedman repeatedly predicted a major revival of inflation that never occurred. In 1982 he predicted 8\% inflation for 1983; the outcome was around 4\%.... In July 1983, Friedman wrote, "We shall be fortunate indeed if we escape either a return to double-digit inflation or renewed recession in 1984... In August 1983, he said, "U.S. inflation rates will rise appreciably in 1984, although it's not yet determined where they'll go from there.”... In April 1984, Friedman said, "I believe [the CPI] will be rising in the neighborhood of 8 to 10 percent in 1985.” Even in November 1985, Friedman said: "Inflation is not dead. It will emerge once again and will be higher next year than it is this year. We almost surely are currently at the bottom of this inflationary episode and are likely to be starting up again.”... Defying these predictions, inflation was consistently below 5\% in every month from 1983 to 1986; moreover, apart from a brief uptick in early 1984, inflation continued to decline after 1982, and was lower in 1986 than it was in 1985" (Nelson 2007). 
Friedman's predictions for the level of activity were also off the mark.

"Mr. Reagan may well face a very difficult situation by next fall," Friedman said in late 1983. "There is a real threat of a recession in the first half of 1984." (NYT, 12/31/83). Instead, real growth continued throughout 1984, and was exceptionally strong in 1984 Q1. "I have no easy explanation of what went wrong," Friedman said after the strong output numbers were released (NYT, 04/30/84).

In Fisher's case, his reputation among economists, at least, has risen. Bad predictions have been forgiven and an understanding of the wide range and relevance of his contribution has risen (Dimand 1998). Perhaps the same will be true of Friedman in the long-run.

\section{Monetary Theory}

\subsection{The Quantity Theory of Money}

Milton Friedman’s writings in monetary economics began with “ The Quantity Theory of Money-A Restatement” in Studies in the Quantity Theory of Money (1956). In this article, Friedman made the case for a revival of the quantity theory of money as a framework alternative to the dominant Keynesian approach to macroeconomics. The quantity theory for Friedman was a theory of the demand for money, a theory of income determination and a theory of the price level. According to Friedman, the quantity theory tradition which had been superseded by the Keynesian Revolution was still alive in the oral tradition of the Chicago School and that his work followed that tradition. ${ }^{2}$ Friedman's Modern Quantity Theory viewed the demand for the stock of

\footnotetext{
${ }^{2}$ Patinkin (1969) and Laidler (1993) dispute Friedman's interpretation of the Chicago School and the quantity theory as developed by Friedman (1956). According to Patinkin, the Chicago School of the 1930s (Simons, Viner and Mints) followed the Fisherian transactions approach to the quantity theory and did not use the Cambridge/Keynesian portfolio balance approach followed by Friedman. Laidler (1993) however sees clear antecedents to Friedman's approach in the works of Ralph Hawtrey and the Harvard economists, Alwyn Young and Lauchlin Currie.
} 
real money balances as a stable function of wealth (real permanent income), the relative prices of a number of important assets (financial and non-financial) and several institutional variables. Friedman's approach followed the Cambridge cash balance tradition of Marshall, Pigou and Keynes which treated money as a temporary abode of purchasing power rather than the transactions approach of Irving Fisher’s Purchasing Power of Money (1911). Friedman ( 1956) does not cite Fisher although in his earlier “ The Methodology of Positive Economics “ ( 1953) refers to Fisher along with David Hume, the Cambridge School and Keynes as originators of major variants of the quantity theory. Several years later, Friedman clarified his position:

"A more fundamental and most basic development in monetary theory has been the reformulation of the Quantity Theory of Money in a way much influenced by Keynesian liquidity analysis. That reformulation emphasizes money as an asset that can be compared with other assets; its emphasis is on what is called "portfolio analysis", analysis of the structure of peoples' balance sheets, of the kind of assets they want to hold. This emphasis looks at monetary theory as part of capital theory or the theory of wealth. This is a rather different emphasis on transactions and money as a mechanical medium of exchange somehow connected with the transactions process." (Friedman 1964, republished as chapter 3 in Friedman 1969 and 2006, 730)

However in later work, beginning in 1970, Friedman gave ample attention to Irving Fisher's seminal work on the quantity theory. In (1970a) he places Fisher at center stage in the monetarist counter-revolution.

“ A counter-revolution must be preceded by two stages; an initial position from which there was a revolution... . I would like first to make a few remarks about the initial position and the revolution... The initial position I shall call the quantity theory of money and associate it largely with the name of an American economist, Irving Fisher, although it is a doctrine to which many prominent English economists also made contributions. The revolution... was made by Keynes in the 1930s. Keynes himself was a quantity theorist, so that his revolution was from, as it were, within the governing body. Keynes's name is the obvious name to attach to the revolution. The counter-revolution also needs a name--one most widely used in referring to it is 'the Chicago School' (Friedman 1970a, $1)$. 
In 1970b and also in (1982) Friedman goes through Fisher's equation of exchange in great detail:

"The most famous version of the quantity equation is doubtless the transactions version popularized by Irving Fisher (Fisher 1911, 24-54):

$$
\mathrm{MV}=\mathrm{PT} \quad(1)
$$

or

$$
\mathrm{MV}+\mathrm{M}^{\prime} \mathrm{V}^{\prime} \text { (2) “ }
$$

Where $\mathrm{M}$ is the stock of currency, $\mathrm{M}^{\prime}$ the stock of demand deposits payable by check, $\mathrm{T}$ the volume of transactions, $\mathrm{V}$ the velocity of circulation of currency and $\mathrm{V}$ ' the velocity of circulation of deposits, and $\mathrm{P}$ a price index.

Friedman (1970b and 1982) discusses the problems in empirically implementing Fisher's quantity equations, especially those in measuring capital transactions and he makes the case for the income form of the equation of exchange.

" Despite the large amount of empirical work done on the transactions equations, notably by Irving Fisher and Carl Snyder ( Fisher 1911, 280-318, Fisher 1919, Snyder 1934), the ambiguity of the concept of "transactions" and the " general price level", particularly those arising from the mixture of current and capital transactions-were never satisfactorily resolved. The more recent development of national income accounting has stressed income transactions rather than gross transactions and has explicitly and satisfactorily dealt with the conceptual and statistical problems of distinguishing between changes in prices and changes in quantities. As a result, the quantity theory has more recently tended to be expressed in terms of income rather than of transactions." (Friedman 1970b, 198).

Further Friedman (1988) discusses why Friedman and Schwartz, Monetary Trends (1982) do not include Fisherian transactions variables in their demand for money function:

" The idea that renders this approach attractive is that there is mechanical link between a dollar of payments per unit of time and the average stock of money required to effect it — a fixed technical coefficient of production as it were. It is clear that this mechanical approach is very different in spirit from the one we have been following. On our approach, the average amount of money held per dollar of transactions is itself regarded as a resultant of an economic equilibrating process, not as a physical datum... If for whatever reason, it becomes more expensive to hold money, then it is worth devoting 
resources to effecting monetary transactions in less expensive ways or to reducing the value of transactions per dollar of final output. In consequence, our ultimate demand function for money in its most general form does not contain as a variable the volume of transactions or of transactions per dollar of final output; it contains rather more basic technical and cost conditions that affect the costs of conserving money, be it by changing the average amount of money held per dollar of transactions per unit of time or by changing the number of dollars of transactions per unit of time or by changing the number of dollars of transactions per dollar of final output... “(Friedman 1988, 222).

Despite his differences with Fisher, Friedman draws heavily on Fisher's analysis of the basic cash balance adjustment mechanism of the quantity theory. Friedman’s (1969, 4-6), famous example of a helicopter doubling the quantity of money reads very much like Fisher's discussion in the Purchasing Power of Money (1911, 153-154).

According to Friedman:

"Let us suppose now that one day a helicopter flies over this community and drops an additional \$ 1000 in bills from the sky... If every individual simply decided to hold onto the extra cash, nothing else would happen. Prices (and nominal income) would remain what they were before, and income would remain at $\$ 10,000$ per year. The community's cash balances would simply be 10.4 weeks income instead of 5.2. But this is not the way people would behave. Nothing has occurred to make the holding of cash more attractive than it was before... The assumption that he [ an individual] was in a stable equilibrium position before means that he will now want to raise his consumption and reduce his cash balances at some rate. He will do so by trying to spend more than he receives. But one man's expenditure is another man's receipt. The members of the community as a whole cannot spend more than the community as a whole receives... People's attempts to spend more than they receive will be frustrated, but in the process these receipts will bid up the nominal value of services" ( and since real output is assumed by Friedman to be determined by Walrasian general equilibrium, prices).

Compare this to Fisher( 1911):

"Suppose... that a doubling in the currency and circulation should not at once raise prices, but should halve the velocities instead... [p \}rices being unchanged [an agent] now has double the amount of money in deposits which his convenience has taught him to keep on hand. He will then try to get rid of the surplus money and deposits by buying goods. But as somebody else must be found to take the money off its hands, its mere transfer will not diminish the amount in the community. It will simply increase somebody else's surplus. Every 
body has money on his hands beyond what experience and convenience have shown to be necessary. Everybody will want to exchange this relatively useless extra money for goods. No one can deny that the effect of every one's decisions to spend more money will be to raise prices... the only way to get rid of a plethora of money is to raise prices to correspond." [Emphasis ours]. (Fisher 1911, 153-4 from Laidler $(1991,76$.

Friedman in other writings voices his debt to Fisher’s quantity theory analysis. In his 1972 American Economic Review article indicting the Federal Reserve for precipitating the Great Inflation, Friedman reflected on an earlier AEA session in 1910 in which Fisher (1911b) debated Laurence Laughlin on the causes of the mild inflation observed since 1896. Laughlin rejected the quantity theory and attributed the inflation to wage push and other non-monetary forces. Fisher attributed it to increases in the quantity of money.

According to Friedman:

"Irving Fisher began his response, "I find myself unable to agree with most of the positions taken by Professor Laughlin in his able paper. In my opinion, "Fisher went on, "the old quantity theory is in essence correct. What it needs is to be restated, not rejected" (Fisher 1911b, 35). And now I must cease quoting from Fisher, with whom I am in total agreement, and proceed instead to plagiarize him —albeit with modifications to bring him down to date.” (Friedman 1972, 12).

Finally, Friedman and Schwartz in Monetary Statistics of the United States (1970) acknowledge their obligation to Fisher for his earlier empirical work in the Purchasing Power of Money in constructing their money supply series. Unlike Fisher they treat demand deposits as money and their definition of money as a temporary abode of purchasing power also includes time deposits. In their reconstruction of existing series of currency and deposits they praise Fisher's earlier work. Some of Fisher's data is incorporated in their final data series.

"However, only three [earlier researchers] constructed estimates for the period before World War I that are sufficiently close to our own to justify detailed attention... 
Irving Fisher, who constructed estimates of currency held by the public and deposits, 1896-1901...” (Friedman and Schwartz 1970, 260).

\subsection{The Fisher effect}

Friedman incorporated Fisher's famous relationship between the nominal interest rate and expected inflation into his main theoretical and empirical work in money almost from the beginning. In Friedman‘s “The Quantity Theory of Money—A Restatement” (1956), although

Fisher is not cited, the Fisher equation is included in his discussion of the rates of return on bonds and equities as arguments in the demand for money (Friedman 1956, 9).

Later with the buildup of inflation in the mid 1960s Friedman (1968a and 1970a) and especially with Schwartz in Monetary Trends (1982) gives extensive coverage to the Fisher effect. In chapter 10 of Monetary Trends, "Money and Interest Rates" in describing the state of knowledge in 1966 when they wrote the first draft of the chapter:

"Irving Fisher's path breaking work, dating from 1896, distinguishing between nominal and real interest rates and examining the empirical role of inflationary expectations was hardly known and was certainly not part of the received wisdom. Accordingly our first draft, which presented a full theoretical analysis incorporating Fisher's work was devoted to testing his conclusions with our U.S. data." (Friedman and Schwartz 1982, 477)

Friedman and Schwartz then describe the explosion of literature on the Fisher effect that followed in the 1960s and 1970s;

“ The first round of the explosion, like our first draft, consisted largely of studies along the lines pioneered by Irving Fisher (1896, 1907, 1930) both redoing his work and extending it by introducing more sophisticated devices for estimating inflationary expectations. These studies largely confirmed Fisher's results-in particular, his conclusion that inflationary expectations were formed on the basis of a long past period and only slowly adjusted to experience. This condition was the centerpiece of his work 
and the basis for his interpretation of the Gibson's paradox - the long observed correlation between interest rates and the level of prices.” (Friedman and Schwartz 1982, 478).

In chapter 10, section 10.1 “Theoretical analysis” in Monetary Trends Friedman and_Schwartz in analyzing the effects of monetary changes on interest rates, distinguish between the short-run liquidity effect, the medium-run income effect, and the long-run price anticipation effect attributed to Fisher.

"When in our example, prices are rising at 5 per cent a year, the public will come sooner or later to anticipate the price rise. As a result, the 4 per cent initial interest rate can no longer be the equilibrium rate. We can no longer neglect the distinction to which Irving Fisher called attention between the nominal rate of interest and the real rate of interest. Initially both equaled 4 per cent. If the nominal interest rate were to stay 4 per cent, the real yield would be -1 per cent. Nothing has happened in the real sector. In the tentative equilibrium resulting from the impact and income effects alone, to reduce the equilibrium real yield. As the inflation comes to be anticipated, lenders will come to demand higher interest rates and borrowers will be willing to pay higher interest rates. The nominal interest rate must rise above its initial level” (Friedman and Schwartz 1982, 490).

Friedman and Schwartz $(1982,583)$ also attributed to Fisher the important difference between ex post and ex ante real interest rates. Fisher's analysis is important in the derivation of Friedman and Schwartz’s long-run money demand function. In discussing the “ Relation Between Yields on Nominal and Real Assets" they argue that "for the purpose of studying monetary influences on interest rates — to follow Fisher and assume that the ex post real return on physical assets can be taken to be roughly constant on the average over time..” ( Friedman and Schwartz 1982, 522) and in footnote 48, they state “ As Fisher says in his chapter 'Inductive Verification ( Monetary)' in The Rate of Interest ( 1907)," “ In general the latter factor - unforeseen monetary change is the more important [compared with factors affecting the real rate on physical assets] ... it is of course, not to be assumed that commodity interest [the real yield] ought to be absolutely 
invariable; but it is practically certain that its variation would not be three and a half times the variations in money interest, unless the price movement were inadequately perceived' (1982, 279-80). Friedman and Schwartz further reference Fisher;

In the chapter in his later book, The Theory of Interest ,in which he presents his statistical calculations relating interest rates to past price change, Fisher does not explicitly discuss the constancy or variability of the real return on physical assets until the final two sentences of the chapter.. He writes ' while the main object of this book is to show how the rate of interest would behave if the purchasing power of money were stable, there has never been any long period of time during which this condition has been even approximately fulfilled. When it is not fulfilled, the money rate of interest, and even more the real rate of interest [i.e the ex post real return on nominal assets] is more affected by instability of money than by those more fundamental and more normal causes connected with income impatience and opportunity to which this book is chiefly devoted ' (Fisher 1907, 451).

\subsection{Gibson's Paradox}

Friedman and Schwartz ( 1982) revisits the debate over Gibson’s paradox, the positive correlation between nominal interest rates and the price level discussed by Keynes in The Treatise on Money Volume 2 ( 1930). Fisher (1907) explained the phenomenon in terms of lagged adjustment of inflationary (deflationary) expectations to actual price change. He argued that it takes time for market agents to form expectations and that expectations of future price change would be formed based on past observed price change. Consequently the reason we observe the paradox of the price level (not the inflation rate) and interest rates moving together over long periods of time is because interest rates adjust slowly to rising or falling prices.

"Suppose an upward movement of prices begins. Business profits (measured in money) will rise... Borrowers can now afford to pay higher 'money interest'. If however, only a few persons at first see this, the interest will not be fully adjusted, and borrowers will realize an extra margin of profit after deducting interest charges. This raises an 
expectation of a similar profit in the future and this expectation, acting on the demand for loans, will raise the rate of interest. If the rise is still inadequate, the process is repeated, and thus by continual trial and error the rate approaches the true adjustment" (Fisher 1907, 284-285).

By contrast, Wicksell (1907) and later Keynes (1930) explained the paradox in terms of movements in the rate of interest. According to their argument, real forces such as technological progress and businessmen's expectations explain long swings in the real yield on capital. Thus in the case of the upswing in the business cycle, the natural (real) rate of interest would rise creating a rising demand for loanable funds. Faced with the rising demand for loanable funds, banks would increase their loans and create money, letting their reserve ratios drop. Eventually they would react to their declining reserve ratios by raising their lending rates. Hence we would observe interest rates rising with prices.

To test his explanation, Fisher (1930, 407-44) constructed a measure of the expected rate of price change as a weighted average of present and past changes.

"[Fisher] developed distributed lags, and he applied them to the problem. He expressed the nominal interest rate as the sum of a real interest rate, implicitly assumed constant, and an anticipated rate of price change, and then approximated the anticipated rate of price change by a weighted average of prior price changes with the weights declining linearly and summing to unity - that is a triangular weighting pattern” (Friedman and Schwartz 1982, 547).

Fisher performed these calculations using annual British data 1815-1914 and U.S. data 18701914 for both short-term and long-term securities. Fisher then correlated the levels of interest rates with his measure of anticipated price change-increasing the length of the lags until $\mathrm{R}^{2}$ was maximized. He found that the mean lag that maximized $\mathrm{R}^{2}$ was 10 years (the average of his experiments). 
Friedman and Schwartz (1982, 548-565) discuss later criticisms of Fisher's analysis and subsequent studies (some by Friedman's students). The evidence generally corroborates Fisher's analysis for the pre World War I period, but finds shorter lags in the interwar period and no relationship after World War II.

“ Any shortcoming of Fisher's explanation of Gibson's paradox does not... in any way diminish the importance of his distinction between real and nominal interest rates, or his distinction between ex post and ex ante real yields , or his emphasis on the anticipated rate of price change in affecting both the demand and supply of loanable funds. But that it does put in serious doubt his highly specialized composite hypothesis that for the purpose of studying the influence on interest rates the ex ante real rate can be treated as a constant, and that interest rates follow the level of prices because borrowers and lenders estimate future inflation by a long weighted average of past rates of inflation” (Friedman and Schwartz 1982, 553).

Friedman and Schwartz's own estimates for the episodes covered by Fisher find lags of adjustment somewhat shorter than does Fisher,

"All in all, the net result of these additional calculations is to reinforce our earlier suggestion that Fisher's hypothesis is plausible for the pre World War I period, somewhat plausible for the interwar period, but not at all plausible for the Post World war II period. “(Friedman and Schwartz 1982, 563).

Friedman and Schwartz $(1982,564)$ like Cagan $(1965)$ reject the competing Wicksell/Keynes hypothesis although later literature (Benjamin and Kochin 1984) and Barsky and Summers (1988) are somewhat more sympathetic.

Friedman and Schwartz $(1982,630)$ conclude their book by lauding Fisher as an early progenitor of the idea of rational expectations.

"Irving Fisher was an early and sophisticated user of the basic idea of rational expectations. His expectation (in 1896) that nominal interest rates would be relatively high during periods of rising prices and relatively low during periods of falling prices was based on the view that lenders and borrowers seek to anticipate price movements and allow for them in the interest rates they are willing to accept or pay. His examination of empirical evidence persuaded him that there was an effect in this direction but that it was 
very much damped - the conclusion that we too have reached on the basis of experience for a much longer period. He suggested an explanation in terms of the slowness with which participants adopted their anticipations, leading to an appearance that interest rates vary with the price level rather than the rate of change."

\subsection{Money and Business Cycles}

Friedman and Schwartz (1963) "Money and Business Cycles” showed that NBER specific cycles in money growth preceded NBER reference cycle turning points, that the degree of severity of business cycles was closely correlated with the amplitude of cycles of money growth , and that evidence contradicted the view that cycles in money growth were mainly a lagged response to changes in the business cycle. They view Irving Fisher as a predecessor to their approach.

"The topic of money and business cycles has been rather out of fashion for the past few decades. Before the Great Depression, it was widely accepted that the business cycle was a monetary phenomenon, 'a dance of the dollar' as Irving Fisher graphically described it in the title of a famous article."3 (Friedman and Schwartz 1963, chapter 10 in The Optimum Quantity of Money (1969) [2006]

Friedman and Schwartz did not refer to the theory behind Fisher's (1923) empirical analysis. It was based on the Fisher equation and was developed in Chapter IV of The Purchasing Power of Money, "The Transition period".

"The process begins with an initial equilibrium in which prices are steady, hence real and nominal interest rates are equal. The initiating disturbance is an increase in the gold stock. Prices rise as do money profits” ( Steindl 1995, 36. Also see Laidler 1991, 77). But according to Fisher $(1911,59)$ “ the businessman’s profit will rise more... because the rate of interest he has to pay will not adjust itself immediately. "Consequently the real rate is lower, having fallen due

\footnotetext{
${ }^{3}$ Fisher (1935b) also analyzed the transmission of booms and depressions by adherence to a common standard. Friedman and Schwartz (1963 b) make the same point but do not cite Fisher.
} 
to the sluggish adjustment of the rate. This leads to borrowing from the banks and a rise in deposits which raise prices more, also the velocity of currency and deposits rises. These effects further put pressure on prices and temporarily raise transactions (Steindl 1995, 37). The expansion ends when the nominal interest rate rises by the rate of inflation. Nominal rates rise because banks cut back on their lending as their reserves fall (Fisher 1911, 64).

The downswing will then follow because rising interest rates lower asset prices, businesses fail because they cannot renew their loans at former rates (Fisher 1911, 65), the public’s currency money ratio will rise and a bank run may follow. "It is then that the rate of interest rises to a panic figure” (Fisher 1911, 65), leading to a reduction in loans, a decrease in deposits and downward pressure in the price level (Steindl 1995, 37). According to Fisher (1911, 65-66), "This culmination of an upward price movement is what is called a crisis - a condition characterized by bankruptcies, and the bankruptcies being due to a lack of cash when it is most needed” (Fisher 1911, 65-660.).

Fisher’s “dance of the dollar” reflects mainly fluctuations in the price level whereas Friedman and Schwartz focus on real economic activity. Also Friedman and Schwartz do not have a full fledged cyclical model. In their story monetary changes affect the relative rates of return of different assets (both financial and non-financial) in the community's portfolio and by this portfolio balance substitution mechanism then affect the real economy.

\subsection{The Phillips Curve}

One of the key building blocks of the Keynesian revolution that Friedman challenged was the Phillips curve- the notion that there was a permanent tradeoff between the rate of charge of 
money wages (inflation) and the unemployment rate. This view based on A.W. Phillips (1958)

empirical finding of a negative relationship between the rate of change of money wages and

unemployment for the U.K. from the mid-nineteenth to the mid-twentieth century led to

Samuelson and Solow ( 1960) finding a similar relationship between inflation and

unemployment for the U.S. Based on this evidence it was argued that policy makers could trade off lower unemployment for higher inflation.

In his AEA Presidential address in 1968, Friedman demonstrated that the Phillips curve tradeoff could only be temporary reflecting the lagged adjustment by workers to rising inflation. ${ }^{4}$ In the long-run the Phillips curve is vertical. Policy makers can only reduce unemployment below the natural rate by accelerating inflation. When Friedman wrote this paper he was apparently unaware that Irving Fisher had discussed an empirical relationship between price changes and unemployment I “A Statistical Relation between Unemployment and Price Changes “( 1926b). He later acknowledged its importance in a 1974 Institute of Economic Affairs Occasional Paper.

According to Friedman ( 1974) " [t]he discussion of the Phillips curve started with truth in 1926, proceeded through error some 30 years later, and by now has returned back to 1926 and to the original truth” ( Friedman 1974, 63)

“Fisher's article dealt with precisely the same empirical phenomena that Professor A. W. Phillips analyzed in his celebrated article in Economica some 32 years later.... Both were impressed with the empirical observation that inflation tended to be associated with low levels of unemployment and deflation with high levels... There was however a crucial difference between Fisher's analysis and Phillips', between the truth of 1926 and the

\footnotetext{
${ }^{4}$ In that lecture Friedman discussed the Fisher effect when he argued that the central bank could not permanently reduce the market rate of interest below Wicksell's natural rate of interest.
} 
error of 1958, which had to do with the direction of causation. Fisher took the rate of change of prices to be the independent variable that set the process going.”

According to Fisher,

"When the dollar is losing value, or in other words when the price level is rising, a businessman finds his receipts rising as fast, on the average, as this general rise of prices, but not for his expenses, because his expenses consist, to a large extent, of things which are contractually fixed... Employment is thus stimulated-for a time at least. ( Fisher 1926b, 287)”

Further according to Friedman;

"To elaborate his analysis and express it in more modern terms, let anything occur that produces a higher level of spending - or, more precisely a higher rate of increase in spending than was anticipated. Producers would not at first interpret the faster rate of increase in spending as an increase in the demand for this product. The producers of shoes, hats, or coats would discover that apparently there was an increase in the amount of goods they could sell at pre-existing prices. None of them would know at first whether the change was affecting him in particular or whether it was more general. In the first instance each producer would be tempted to expand output, as Fisher states, and also to allow prices to rise. But at first much or most of the unanticipated increase in nominal demand... would be absorbed by increases (or fewer increases) in employment and output rather than by increases (or faster increases) in employment in prices. ... Fisher was describing a dynamic process arising out of fluctuations in the rate of spending above some average trend or norm. He went out of his way to emphasize the importance of distinguishing between 'high and low prices on the one hand and the rise and fall of prices on the other' [Fisher 1926b, 288)... The most important distinction-and it is quite clear that this is what Fisher had in mind-is between anticipated and unanticipated changes” ( Friedman 1974, 65).

Friedman then goes on to use the analysis of his 1968 AEA Presidential address to criticize Phillips.

“Professor Phillips' approach was from exactly the opposite direction [as Fisher]. He took the level of employment to be the independent variable that set the process going. He treated the rate of change of wages as the dependent variable. His argument was a very simple analysis-I hesitate to say simple-minded, but so it has proved-in terms of static demand and supply conditions.” (Friedman 1974, 66). 
Friedman then criticizes Phillips for treating the demand and supply of labor as a function of nominal wages as opposed to real wages, which he attributes to Keynesian thinking.

"From this point of view, the essential element of the Keynesian revolution was the assumption that prices are highly rigid relative to output so that a change in demand of the kind considered by Fisher would be reflected almost entirely in output and very little in prices... The simple way to interpret Phillips is that he was therefore assuming the change in nominal wages to be equal to the change in real wages. [But] what he was saying was slightly more sophisticated. It was that changes in anticipated nominal wages were equal to changes in anticipated real wages.” (Friedman 1974, 68).

Friedman then goes on to explain this approach as being based on the Keynesian notion that prices were rigid " in the sense that people in planning their behavior do not allow for the possibility that the price level may change" and that "real wages ex post could be altered by unanticipated inflation "Friedman then shows "that both employers and employees come to recognize that prices in general are rising which then reverses the rate of rise of anticipated real wages and effects the temporary boost to employment” ( Friedman, 1974, 73-74)

\section{Monetary Policy}

Neither Fisher nor Friedman were ivory tower economists. Both studied monetary theory and history with the idea of formulating policies that would improve the general welfare. Here we trace the monetary policy proposals of both men, and the relationships between their proposals.

\subsection{Bimetallism}

Fisher came of academic age during the great battle of the standards -- the gold standard or bimetallism? -- in the late nineteenth century. One of his earliest papers was on the theory of 
bimetallism (Fisher 1894). Bimetallism was bound to attract Fisher: a policy proposal intended to improve the general welfare that could be analyzed by combining theoretical analysis and empirical research. Fisher saw some real merit in bimetallism. The position he adopted was that whether bimetallism improved stability depended on the bimetallic ratio adopted. The bimetallists, led ultimately by William Jennings Bryan, wanted to adopt bimetallism at the traditional ratios (pre-Civil War) of 151/2 or 16 to 1 . By the end of the nineteenth century, however, the world market ratio was far higher. Or to put it somewhat differently, the price at which the bimetallists proposed to coin silver was far higher than the world market price. The mint would be flooded with silver, the money supply would rise substantially, and the price level would rise substantially.

Honest men must regard with horror the proposal to reintroduce a ratio of $151 / 2$ to 1 . But we must not make the error of associating 'debasement' and 'bimetallism' indiscriminately. Bimetallism can be just, if at a ratio equal to the existing ratio, .... It then acts as a sort of insurance against further appreciation of gold (Fisher 1894, 536)

Fisher’s famous paper “Appreciation and Interest” (1896) was also a response to the bimetallic controversy. The key questions motivating the paper were these: How much had debtors lost from the deflation under the gold standard and how much would debtors gain if the deflation could be reversed by adopting bimetallism at the ratio of 16 to 1 .

Fisher was not the first to conceive of the idea that nominal interest rates would adjust to incorporate expected rates of price change. Probably the idea has occurred to many people during periods of sustained price change. In his paper Fisher (1896, 5-9) cites a number of predecessors including John Stuart Mill, Alfred Marshall, Jacob de Haas (1889), and John Bates Clark (1895). Clark's paper was aimed directly at the bimetallists. The deflation after 1879, Clark suggested, had been relatively steady and had been clearly foreseen. Therefore, contractual rates 
had been adjusted (lowered) to reflect the expected deflation. Debtors had lost nothing; it would be wrong to reward them by deliberately creating inflation. There is a reason, however, why we refer to the notion that nominal rates will adjust to reflect the expected rates of price change as the Fisher effect and not as the Clark-Fisher effect or the Haas-Clark-Fisher effect: Fisher's paper was a tour de force. Fisher developed the pure theory of the relationship between real and nominal interest rates and explored many issues that would receive attention decades later including what happens when rates hit the "zero bound" and how the distinction between nominal and real rates affects the use of nominal rates as an indicator of monetary policy. He also drew the implications of his theory for the business cycle. Finally, he put together a large multi-country data base and used it to estimate the extent to which long-term price movements had been incorporated in nominal rates. Fisher, of course, did not have access to modern statistical techniques for analyzing panel data. His ability to squeeze meaningful conclusions from his data given the tools at his disposal was all the more remarkable.

Ironically, given the way we typically use the term "Fisher effect," Fisher's main empirical finding was that the adjustment of nominal rates to sustained price change was typically slow and incomplete. The debtors who had entered into contracts during the post civil war deflation had (contra J.B. Clark) lost something: The real rate they eventually paid was higher than what had been expected when they entered their contracts. ${ }^{5}$

Despite this result, Fisher still concluded that bimetallism at 16 to 1 was a bad idea. Most debts, Fisher noted, were of relatively short duration. Many farm mortgages, for example, ran for only five years. Therefore, most of the debts contracted during the deflation after 1879 had

\footnotetext{
${ }^{5}$ Clark (1896a, 1896b) responded to Fisher's claim. Clark did not offer alternative empirical evidence, but instead reasserted his claim that steady deflation would be incorporated in nominal rates.
} 
already closed: nothing could be done to offset the unexpected losses on those contracts. The inflation to be expected from the adoption of bimetallism at 16 to 1 would overcompensate the debtors for deflation experienced under ongoing debts; it would "defraud the lender" (Fisher 1985, 83). ${ }^{6}$ Mere sympathy for the borrower, moreover, should not blind us to the ethical issues involved in changing standards at the ratio of 16 to 1 .

He [the farmer who borrows money] may lose and all farmers may lose and the causes may be in India or Australia or in the sun spots, but we can scarcely afford to surrender the ancient principle of the Inviolability of Contracts, through sympathy with the misfortunes of any individual man or group of men (Fisher 1895, 84).

In the end, therefore, Fisher concluded, as he had in his theoretical paper on bimetallism, that the Populist plan for bimetallism at 16 to 1 was wrong. But there was now an international dimension to his argument stemming from his new work on interest rates.

As an improvement on the two single standards now existing, bimetallism, launched at the market ratio, may be worth serious consideration. But the proposal now before the world is bimetallism at 15 or 16 to 1 . Such bimetallism means debasement of the standard for any single country which attempts it. If international it means debasement in gold standard countries, and a violent contraction and appreciation in silver standard countries. In no other way could the influence of the legal ratio on the market be felt. We should witness not only losses to creditors in the former countries but losses to debtors in the latter, and these losses would be far in excess of those which we have found to follow from the slow and half foreseen appreciation of the last twenty years (Fisher 1895, 85).

Friedman and Schwartz did not consider the mechanics of bimetallism in detail in $A$ Monetary History and therefore did not cite Fisher's analysis. Bimetallism enters their story as a political force that produced limited attempts to monetize silver and uncertainty about the maintenance of the gold standard that in turn influenced the real economy. They did, however, argue that an early decision in favor of gold or silver would have been clearly better than "the

\footnotetext{
${ }^{6}$ If debts tended to be "rolled over" -- a farmer who remained in debt, for example, by renewing a series of 5-year mortgages with the same lender -- then inflation would correctly compensate borrowers for past losses from unexpected deflation.
} 
uneasy compromise" that prevailed (Friedman and Schwartz 1963, 134). They also ventured a tentative opinion that a return to a bimetallic standard after the Civil War would have been preferable (Friedman and Schwartz 1963, 134, n. 52) to the adoption of a pure gold standard.

Later, Friedman returned to bimetallism in a series of papers reprinted in Money Mischief (1992). In these papers Friedman provided additional evidence supporting the conjecture in $A$ Monetary History that an early adoption of bimetallism would have avoided the deflation under the gold standard thus producing a better behaved price level. Here Friedman acknowledged Fisher's pioneering work on the economics of bimetallism. Indeed, Friedman's late twentieth century research led him to conclusions about bimetallism that reinforced those reached much earlier by Fisher: As a monetary system, bimetallism had much to recommend it when contrasted with a pure silver or pure gold system, but bimetallism in 1896 at 16 to 1 would have been a disaster. Friedman, referring to Schumpeter's claim that Walras provided the best theoretical analysis of bimetallism produced when the controversy over bimetallism was intense, argued that "Irving Fisher's (1911) analysis is equally rigorous and far more accessible" (Friedman 1990, 92).

\subsection{The Compensated Dollar ${ }^{7}$}

Although he saw some potential in bimetallism (at the right ratio of silver to gold) Fisher went on to advocate a modified version of the gold standard that he called the "compensated dollar." ${ }^{8}$

\footnotetext{
${ }^{7}$ This section is based mainly on Fisher's discussion in Stabilizing the Dollar (1920), Patinkin (1992), and Hall (1997). We don't address the empirical question of how well Fisher's plan would have worked in practice. Burdekin, Mitchener, and Weidenmier (2011), however, show that a compensated dollar plan based on silver would have worked well in the late nineteenth century.
} 
The idea -- to judge from Fisher's discussion in Purchasing Power of Money (1911, 337-347) -grew out of his analysis of the gold exchange standards being adopted in the late nineteenth and early twentieth centuries, for example in the Philippines after the American takeover. The basic idea of the gold exchange standard was to fix exchange rates with countries on the gold standard without making gold coins that circulated from hand to hand a part of the money supply, and thus to economize on gold. In the Philippines, for example, silver coins continued to circulate domestically, but they could be used at a fixed rate to purchase bills denominated in gold and payable from a gold reserve held by the Philippines in New York. Since Filipinos did not hold gold coins, moreover, it would be relatively easy to change the exchange rate between the silver coins they did hold and the amount of gold they could purchase with them. Indeed on one occasion the rate had been changed. Why not create a monetary system that took full advantage of the flexibility of the gold exchange standard?

Fisher imagined a monetary base consisting of gold certificates (yellowbacks) backed by a bullion reserve. The yellowbacks would circulate from hand to hand, but instead of being convertible into a fixed sum of gold they would be convertible into a varying amount linked to a general index of prices. The rule Fisher proposed for adjusting the value of the dollar was the essence of simplicity. Whenever the price level exceeded its ideal (par) value, the price of gold would be lowered by the same percentage in the next period. If the price level was 5 percent

\footnotetext{
${ }^{8}$ An alternative scheme to achieve similar results would be widespread indexing of contracts. Fisher discussed indexing in Purchasing Power Parity (1911, 332-37). But while he thought that "there could be no material harm in trying a "permissive" law" (a law that made it legal to use indexed contracts) he saw a number of potential problems, especially if the final result was a mixture of indexed and non-indexed contracts. Milton Friedman also advocated indexation (1974), and noted $(1974,20)$ Fisher's (qualified) support for it. But as Alan Meltzer pointed out to us neither Fisher nor Friedman took into account the effects of a large relative price shock, such as the oilprice shock, on an economy where indexing was widespread. In Brazil in the 1970s, according to Meltzer, this meant that indexation worked to convert a relative price change into a massive inflation that proved extremely costly.
} 
above par, then the monetary authority would lower the price of gold 5 percent; or equivalently one could say the monetary authority would increase the amount of gold in a gold dollar by 5 percent. The holder of dollars would be "compensated" for an increase in the price level by being able to convert his yellowbacks into a larger physical amount of gold. If in the next period the price level was unchanged, and therefore was still 5 percent above par, the price of gold would be lowered another 5 percent. The price of gold, in other words, would continue to fall as long as the price level remained above par.

Suppose we define the percentage difference between the actual price level and the ideal price level as $\mathrm{P}^{\sim}$ and suppose we define the percentage change in the official price of gold made by the monetary authority as Pg*. Then Fisher's proposal could be written as follows. (1) $\operatorname{Pg}^{*}{ }_{t+1}=-P^{\sim}$

But how would compensation set up pressures that would return the price level to par. The simplest way to see what is happening under Fisher's plan is to consider the adjustments under a classic gold standard. Consider the Humean price-specie-flow mechanism. If country X's price level should rise above the long-run international equilibrium because of some arbitrary shock to velocity then country X would experience a balance of payments deficit. Exports would be discouraged because the price in foreign countries (the fixed exchange rate multiplied by the price in $\mathrm{X}$ would rise) and imports would be encouraged because import-competing industries would find their competitive positions eroded. The balance of payments deficit would mean an outflow of gold and hence a downward pressure on the money supply and prices. Fisher's mechanism would reinforce the classic Humean adjustment. A country that experienced a price shock would find its exports decreasing even faster under Fisher's scheme than under a classic 
gold standard because the par rate of exchange would move against the country with rising prices. $^{9}$

One implication of the compensated dollar scheme, as Fisher's recognized and critics pointed out, is that exchange rates would no longer be fixed. And fixed exchange rates were considered one of the major benefits of the classical gold standard. Fisher later acknowledged this criticism and suggested that exchange rate stability could be maintained if all countries simultaneously adopted the compensated dollar scheme. In this case, changes in the world monetary base would be the key and would reflect gold mining and use of gold in the arts and industry. Again it would seem that Fisher's plan would reinforce the classical mechanism. An increase in the price level under the classical gold standard would mean a lower real price of gold, and hence a lower incentive to mine gold. Under Fisher's compensated dollar the real price of gold would fall even further because of coordinated reductions in the nominal price of gold.

Fisher suggested another scheme by which the stock of money could be automatically adjusted to maintain price stability under the compensated dollar scheme. Suppose as before that the monetary base consisted simply of yellowbacks entitling the holder to a fixed amount of gold held in reserve by the government. ${ }^{10}$ Then the value of the gold reserve would be RPg where $\mathrm{R}$ is the gold reserve held by the monetary authority measured in ounces, and Pg is, as before, the price of gold measured in dollars per ounce. The government would, as in a conventional gold standard, create yellowbacks when people deposited new gold in the reserve, and destroy

\footnotetext{
${ }^{9}$ The story, of course, can be made more complex and realistic by bringing in changes in interest rates, the elasticities of exports and imports with respect to price changes, and so on. But the circumstances that would lead to a moderation rather than reinforcement of the classical effects are not obvious.

${ }^{10}$ The story could be made more realistic by making the yellowbacks the monetary base and adding a banking system that created deposits and held yellowbacks in reserve.
} 
yellowbacks when they cashed them in and converted them into gold. Because of changes in the price of gold, however, the amount of yellowbacks circulating in the economy might exceed or fall below the value of the gold reserve. Now suppose that the government adopted a rule of maintaining the gold reserve at $100 \%$ by printing new yellowbacks and depositing them in banks when the gold reserve exceeded the amount of yellowbacks in circulation or cancelling yellowbacks paid in as taxes when the gold reserve fell short of the amount of yellowbacks in circulation. In symbols, the government would follow a policy of maintaining the following equation.

(2) $\mathrm{Mb}=\mathrm{RPg}$

where $\mathrm{Mb}$ is the monetary base; the amount of yellowbacks in circulation.

Combine this relationship with Fisher's price adjustment rule, and hold constant $\mathrm{R}$ and we can see that Fisher has advocated a simple monetary feedback rule.

(3) $\mathrm{Mb}^{*}{ }_{\mathrm{t}+1}=-\mathrm{P}_{\mathrm{t}}^{\sim}$

where $\mathrm{Mb}^{*}$ is the percentage change in $\mathrm{Mb}$.

The monetary base would be reduced, other things equal, as long as the price level was above par.

The quantity theory interpretation of the compensated dollar, sketched above, was somewhat hidden in Stabilizing the Dollar. The reason, as Fisher explains, is that the quantity theory was controversial. Many people who rejected the quantity theory held some form of commodity theory of the price level. For them, prices were determined by the amount of precious metal in the currency. Fisher wanted to broaden the appeal of his proposal by showing 
believers in commodity theories of the price level that his scheme was something they could support.

\subsection{A Price Stability Mandate for the Federal Reserve}

During the 1920s Fisher was persuaded by the apparent success of the Federal Reserve in maintaining price stability -- a period Friedman and Schwartz later referred to as the "High Tide of the Federal Reserve System" -- that the Federal Reserve could manage the money supply so as to maintain price stability. It was, as Fisher saw it, the story of the leadership of the Federal Reserve by Benjamin Strong Jr., the highly regarded Governor of the Federal Reserve Bank of New York. Fisher now argued that the Federal Reserve could and should maintain price level stability by controlling the stock of money through open market operations and changes in the discount rate. Fisher's main concern was that the stability enjoyed in the 1920s depended on the understanding and leadership of one man. Fisher wanted to institutionalize a price stability rule. He later explained all this in a remarkable letter to Clark Warburton found by Thomas Cargill (1992). Fisher explained his support of a legal mandate for price stability as follows.

... I tried for years to get through Congress a simple bill to require the Federal Reserve System "to use all it powers" to stabilize the price level. This was called the Strong Bill, named after Congressman Strong of Kansas, no relative of Governor Strong. Governor Strong said to me, "if you get that bill passed I will resign. Let me alone. God save me from my friends. If you will let me alone I will try to do the best I can but if you make me do by law what I am trying to do without legislative control, I will be so afraid that I cannot fill the bill that I will not accept the responsibility." I have always believed that had Governor Strong lived, we would not have had the tragic depression following the stock market crash in 1929 or so big a crash to start with. I think the realization of what was going to happen shortened his life. He had because of illness resigned in 1927 and died in 1928. I was told that he paced the floor in distress realizing that his policies were being abandoned. When he made the above remark to me I said: "Governor Strong I will trust you as long as you live but you will not live forever and when you die I fear that your policies will die with you." (Fisher to Warburton 1946, Cargill (1992, 1274). 
In the same letter Fisher went on to explain that the failure of the Federal Reserve to stem the depression resulted from a realization of what he had feared in the 1920s -- that leadership would end up in the hands of someone who did not understand the basic relationships among monetary policy, the stock of money, and the price level.

In fact, after he [Strong] died, and after the crash, I was asleep at the switch until in the summer of 19311 called on Eugene Meyer, the chairman of the Federal Reserve Board. I said: "I am getting alarmed to see demand deposits diminish. It seems to me this may make great trouble." He said: "What did you call the figure?" Amazed, I said: "The full name is individual deposits subject to check without notice." He rang a bell and asked his assistant to bring in the last controller's report open to the page where the figures were given for individual deposits subject to check without notice. In a few minutes the report came in and I pointed and said: "You see that during the last several call dates there has been a continuous reduction." He said, "Yes, I see it." (Fisher to Warburton 1946, Cargill (1992, 1275-76).

Clearly in this letter Fisher was working from an interpretation of the origin of the Great

Depression that was very close, if not identical, to what Friedman and Schwartz developed in A

Monetary History. Friedman and Schwartz were not aware of this letter when they wrote A

Monetary History; if they had been (Friedman told Cargill) they would have cited it extensively.

Friedman and Schwartz did, however, cite a published comment by Fisher that contains the

essence of Fisher's and Friedman and Schwartz's critique of the Federal Reserve.

"Governor Strong died in 1929. I thoroughly believe that had he lived and his policies had been continued, we might have had the stock market crash in a milder form, but after the crash there would not have been the great industrial depression." (quoted in Friedman and Schwartz 1963, 413 n.171.

In advocating a mandate of price stability Fisher was on the same page as Henry Simons and Lloyd Mints at the University of Chicago. The clearest statement of the case for a price rule is to be found in Simons' famous paper "Rules vs. Authorities” (1936). Here Simons considered 
but rejected the case for a monetary rule on the grounds that defining a single stable monetary aggregate would not be possible. Simons might have cited, indeed probably should have cited, Fisher as an important authority who had advocated the same (or at least a very similar) goal, but did not. According to Don Patinkin the Chicago economists tended to distance themselves from Fisher in the 1930s because by that time Fisher had come to be regarded as something of a crank (Dimand 1998, 206; Patinkin 1993). It was unfair to Fisher's contribution to monetary economics, but the Chicago economists, like Fisher, were anxious to get their plans adopted, and Fisher, the vegetarian prohibitionist who made wildly inaccurate predictions about the stock market, and advocated stamped money (see below), was no longer a voice of authority that added weight to an opinion.

There was also a matter of style. Henry Simons did not cite Fisher in "rules vs. authorities;" but then Simons generally did not waste a lot of ink citing his predecessors. There is no list of references and no names mentioned in footnotes in his famous paper. Lloyd Mints, on the other hand, did cite Fisher frequently in A History of Banking Theory (1945). Mints (1945, 272, n. 33) includes Fisher in a large group of economists who had supported some form of price stability mandate. In Monetary policy for a competitive society Mints $(1950,126)$ describes Fisher as the "stoutest advocate of price level stabilization" in recent years although he claims that Simons, his former colleague, was "the most convincing."

Milton Friedman (1959) followed in Simon's tradition and advocated a monetary rule, but broke with Simons and advocated a monetary growth rule rather than a price stability rule. Friedman saw the problems of choosing a particular monetary aggregate as less important than Simons. Friedman believed that the monetary aggregates tended to move together and hence the 
goal of monetary stability could be attained by choosing any of them. And Friedman believed that the loose connection between money and prices created a problem for price level targets. How could the Federal Reserve be held accountable for missing a target when so many unforeseeable events could prevent them from hitting it? Here Friedman echoed the concerns that Benjamin Strong had expressed to Fisher. "If you will let me alone I will try to do the best I can but if you make me do by law [stabilize prices] what I am trying to do without legislative control, I will be so afraid that I cannot fill the bill that I will not accept the responsibility."

Friedman always insisted that he had proposed a monetary growth rule as the best that could be achieved given the limited state of understanding of monetary economics. Later, Friedman was impressed by Allan Greenspan's handling of monetary policy and praised Greenspan without insisting that a monetary growth rule would have produced greater economic stability. In this respect Friedman's response to Greenspan was similar to Fisher's response to Benjamin Strong.

\subsection{Stamped Money}

In the wake of the collapse from 1929 to 1933 Fisher (Fisher, Cohrssen, and Herbert Wescott Fisher 1933; Fisher, and Herbert Wescott Fisher 1934) championed a radical scheme for ending the depression: stamped money. Fisher had no doubt that expansionary open market operations could increase the money supply. But at the height of the slump he feared that the increase in bank reserves would not be lent out or that an increase in currency would be hoarded. So he proposed an alternative, stamped money, that he thought would increase velocity. At the same time the Chicago economists, Mints and Viner, had similar concerns about the 
effectiveness of monetary expansion, and their preferred remedy to offset the depression was money financed fiscal expansion (Steindl 1995, 86-92, 105). For similar reasons, Fisher abandoned his earlier theory of the business cycle, chapter 4 of Purchasing Power of Money, in favor of his Debt-Deflation theory of the Depression (Fisher 1933). ${ }^{11}$

The basic idea of stamped money was simple. Currency would be issued (by the central government or even by a local government) to pay for its expenses. Unlike ordinary currency, however, stamp scrip would require that a tax be paid on the money at regular intervals. If the tax was not paid, the value of the scrip as currency would be reduced. On a specified date from the time of issue, for example, a $\$ 1.00$ bill would sink in value to, say, $\$ .95$ cents unless a $\$ .05$ stamp was purchased for the bill. The tax might be paid at the local post office where the bill would be stamped to show that the tax had been paid. The point was to get more money into circulation and give people an incentive to spend their money rather than hoard it. In advocating stamped money Fisher was again reacting to current events. Hundreds of communities in the United States and around the world were issuing scrip as a way of meeting budget deficits, and providing currency for local communities hard hit by bank failures. Scrip, of course, does not have to be stamp scrip. It was often simply an IOU issued by a local government, perhaps issued in a convenient denomination with the hope that it would circulate as money in the local community. But some communities did experiment with stamped money; following the ideas of Silvio Gesell, a German merchant and economist whose writing were the economic and spiritual guidebooks for the stamped scrip movement. Fisher with his usual energy and enthusiasm threw

${ }^{11}$ According to Dimond (2000) Fisher abandoned the quantity theory explanation of the Great Depression and as alternative proposed his debt-deflation theory because he believed that velocity was unstable. Later in the 1930s he became convinced that the apparent instability of velocity was an artifact produced by the misclassification of deposits by banks that were evading reserve requirements, and he returned to the quantity theory in the last decade of his life (Dimond 2000, 345). 
himself into movement, setting up a kind of clearing house for information about stamped money and carrying on a vast correspondence with communities looking for advice on how to issue stamped money.

Keynes (1936, chapter 23) also wrote favorably about Gesell and stamped money. But stamped money did not impress the Chicago economists in the 1930s. In his critique of the Beveridge Report Simons $(1945,236)$ ventured simply that "I have never liked the GesellFisher-Dahlberg schemes," one of his few references to Fisher. Friedman, as far as we have been able to determine, did not take up the idea of stamp scrip. However, in the case of another "wild scheme" that emerged in the darkest days of the Depression Fisher and the Chicago economists were on the same page.

\section{$4.5100 \%$ Reserves}

The basic idea of $100 \%$ money, like the other reforms Fisher championed, is ultimately very simple. Banks would be required to hold $100 \%$ of their deposits in reserve rather than being permitted to hold fractional reserves banks. Banks would become simply warehouses for money. To earn a profit they would have to charge fees for storing and transferring cash. Although if the government paid interest on reserves held at the Federal Reserve, as has recently become the case, the banks would have another source of income.

The point of $100 \%$ reserves is that it would make impossible in the future the kind of collapse of the money supply that had occurred between 1929 and 1933. The amount of highpowered money had not declined drastically, but the money multiplier had. The multiplier is a function of the reserve ratios of the banks, which had risen, and the currency deposit ratio of the 
public which had also risen. Under 100\% reserves the money multiplier would always be one. Fisher believed that with the adoption of $100 \%$ reserves and one of his schemes for controlling the monetary base, price level stability and hence stability of the real economy could be achieved.

As usual, Fisher was advocating a fundamental reform that was a logical extension (to him) of current trends. Like many economists at the time Fisher (1936) looked at the large excess reserves that banks had been building up simply as a ammunition for a future inflation that could be defused by raising required reserve ratios. He also pointed out that charging depositors, especially small depositors, for depositing, withdrawing, and transferring their funds had become common. The moment seemed propitious for imposing 100 percent reserves.

Fisher (1936) acknowledged that the case for 100 percent reserves had first been made during the depression in a mimeo circulated by Simons and other members of the economics department at Chicago, although Fisher indicated that the same idea had occurred in earlier great depressions. Fisher also acknowledged the contributions to the development of the idea made by other economists in the debate that was inspired by the Chicago memo. Fisher saw his contribution, evidently, as he had in the case of stamped money, as absorbing the thinking of his fellow economists, and then packaging these radical sounding ideas in a form that would persuade the public. Although these crusades, like his others, went nowhere, it is unlikely that anyone else could have done a better job: Fisher could write swiftly, draw on a large store of historical and current examples, and find striking metaphors with which to illustrate his argument. 
Milton Friedman (1959, 65-75) made 100 percent reserves one of the key elements in his Program for Monetary Stability. Friedman (1959, 108, n.9) referred to the work of Simons and Mints as well as several journal articles as his starting point, but did not mention Fisher's work on 100 percent reserves. Given Fisher's popularizing purpose, this is perhaps understandable. Like Fisher, Friedman pointed to a recent development in the economy, in this case the massive purchase of government bonds by banks during World War II, to illustrate the feasibility of the proposal. In a Program for Monetary Stability, incidentally, Friedman claimed to have modified the Chicago plan, as 100 percent reserves was sometimes known, in only one way: having the Federal Reserve pay interest on reserves. This reform was finally adopted in the wake of the 2008 crisis.

\section{Conclusion}

Irving Fisher had considerable influence on Milton Friedman's monetary economics. Although Friedman's revival of the quantity theory was not based on Fisher's transactions approach, Friedman acknowledged Fisher as one of the founding fathers. The Fisher effect of anticipated inflation on nominal interest rates was a key building block in Friedman and Schwartz's theoretical and empirical work in the 1970s and 1980s. Indeed Fisher's development of distributed lags were a key component in Friedman's empirical work and that of some of his students. Friedman and Schwartz also lauded Fisher's monetary theory of the business cycle as a predecessor to their work although they did not adopt Fisher's theoretical framework. Finally

Friedman acknowledged Fisher as having sketched out a critique of the Phillips curve 40 years before he did. 
Both Fisher and Friedman as adherents to the quantity theory favored reforms to the monetary system within that framework. Fisher's proposals included the compensated dollar which was a scheme to stabilize the price level by altering the gold content of the dollar. But this was equivalent to stabilizing the monetary base and the money supply. Later, in the 1920s Fisher was a staunch advocate of the Strong Bill which would have mandated the Federal Reserve to follow a price stability target. Friedman, operating in a different monetary regime proposed his k- percent rule of steady and known monetary expansion. Later he favored freezing the monetary base and thereby creating the optimum quantity of money which brought him close to one of Fisher's early proposals. Both Fisher and Friedman, moreover, were advocates of 100 percent reserves. Fisher's debt-deflation theory of the depression and his stamped money proposal were temporary departures from his earlier emphasis on the supply of money which Friedman did not embrace. Both Fisher and Friedman blamed the Federal Reserve for creating the Great Depression and both believed that had Benjamin Strong lived that the outcome would not have been nearly as dire. And both believed that some sort of legal mandate should be instituted so that good policy did not depend on anyone individual being at the helm of the Federal Reserve. In sum, Irving Fisher was a pioneer Friedmanian; and Milton Friedman was a latter day Fisherian.

Assessing the influence of an earlier economist's writings on that of later scholars is a challenge. As a science progresses the views of its earlier pioneers are absorbed in the weltanschauung. Fisher's Purchasing Power of Money as well as the work of Pigou and Marshall were the basic building blocks for later students of monetary economics. Thus, the Chicago School of the 1930s absorbed Fisher's approach, and Friedman learned from them. However, in 
some salient aspects of Friedman's work we can clearly detect a major direct influence of Fisher's writings on Friedman's. Thus, for example with the buildup of inflation in the 1960s Friedman adopted the Fisher effect and Fisher's empirical approach to inflationary expectations into his analysis. Thus, Fisher's influence on Friedman was both indirect through the Chicago School and direct . Regardless of the weight attached to the two influences, Fisher's impact on Friedman was profound. 


\section{References}

Barsky, Robert B., and Lawrence H. Summers. 1988. Gibson's paradox and the gold standard. Journal of Political Economy 96 (3) (06): 528-50.

Benjamin, Daniel K., and Lewis A. Kochin. 1984. War, prices, and interest rates: A martial solution to Gibson's paradox. In A retrospective on the classical gold standard, 1821-1931., ed. Anna J. Schwartz, 587-604. National Bureau of Economic Research Conference Report series. Chicago and London: University of Chicago Press.

Burdekin, Richard C.K., Kris James Mitchener, nd Marc D. Weidenmier. (2011) "Irving Fisher and Price-Level Targeting in Austria: Was Silver the Answer?" National Bureau of Economic Research, Working Paper 17123.

Cagan, Phillip. 1965. Determinants and effects of changes in the stock of money, 1875-1960. Studies in business cycles. Vol. 13. New York: National Bureau of Economic Research ; distributed by Columbia University Press.

Cargill, Thomas F. 1992. Irving Fisher comments on Benjamin Strong and the Federal Reserve in the 1930s. The Journal of Political Economy 100 (6, Centennial Issue) (Dec.): pp. 12731277.

Clark, John B. 1896a. The after effects of free coinage of silver. Political Science Quarterly 11 (3) (Sep.): pp. 493-501.

1896b. Free coinage and prosperity. Political Science Quarterly 11 (2) (Jun.): pp. 248258.

1895. The gold standard of currency in the light of recent theory. Political Science Quarterly 10 (3) (Sep.): pp. 389-403.

Dimand, Robert W. 2005. Irving Fisher on the international transmission of booms and depressions through monetary standards. In The economics of deflation. volume 1., ed. Pierre L. Siklos, 272-282. International Library of Critical Writings in Economics series, vol. 189. An Elgar Reference Collection; Cheltenham, U.K. and Northampton, Mass.:; Elgar.

. 2003. Competing visions for the U.S. monetary system, 1907-1913: The quest for an elastic currency and the rejection of Fisher's compensated dollar rule for price stability. Cahiers d'Economie Politique(45) (Autumn): 101-21. 
- 2003. Irving Fisher on the international transmission of booms and depressions through monetary standards. Journal of Money, Credit and Banking 35 (1) (Feb.): pp. 49-90.

- 2000. Irving Fisher and the Quantity Theory of Money: the Last Phase. Journal of the History of Economic Thought, vol 22, no, 3, 329-345.

1999. Irving Fisher and the Fisher relation: Setting the record straight. The Canadian Journal of Economics / Revue Canadienne d'Economique 32 (3) (May): pp. 744-750.

. 1998. The fall and rise of Irving Fisher's macroeconomics. Journal of the History of Economic Thought 20 (2) (06): 191-201.

. 1997. Irving Fisher and modern macroeconomics. American Economic Review 87 (2) (05): 442-4.

Dimand, Robert W., and John Geanakoplos. 2005. Celebrating Irving Fisher: The legacy of a great economist. American Journal of Economics and Sociology 64 (1) (01): 3-18.

Fisher, Irving. 1936. 100\% money and the public debt. Economic Forum Spring (April-June): 406-20.

. 1935a. 100\% money; designed to keep checking banks 100\% liquid; to prevent inflation and deflation; largely to cure or prevent depressions; and to wipe out much of the national debt. New York: Adelphi.

. 1935b. Are booms and depressions transmitted internationally through monetary standards:? International Statistical Institute Bulletin.

. 1933. The debt-deflation theory of great depressions. Econometrica 1 (4) (Oct.): pp. 337-357.

- 1930 [1986] The theory of interest: As determined by impatience to spend income and opportunity to invest it. Reprints of economic classics. Fairfield, NJ: A.M. Kelley.

— 1926a. Prohibition at its worst. New York: The Macmillan Company.

_ 1926b. "A statistical relation between unemployment and price changes. International Labor Review 6 (June): pp. 785-792.

- 1923. The business cycle largely a dance of the dollar. Journal of the American Statistical Association 18 (144) (Dec.): pp. 1024-1028. 
- 1922. The making of index numbers; a study of their varieties, tests, and reliability. Publications of the Pollak foundation for economic research. Vol. 1. Boston, New York: Houghton Mifflin Company.

. 1920. Stabilizing the dollar : A plan to stabilize the general price level without fixing individual prices. New York: Macmillan Co.

—. 1919. Money, Prices, Credit, and Banking. American Economic Review (June): 407-9.

- 1914. Objections to a compensated dollar answered. The American Economic Review 4 (4) (Dec.): pp. 818-839.

_ 1911a. (with Harry Gunnison Brown) The purchasing power of money : Its determination and relation to credit, interest and crises. New York: The Macmillan co.

_ . 1911b. Recent Changes in Price Levels and their Causes, Bull. Amer. Econ. Assoc., Fourth Series, No. 2, 1, Apr. 1911, 36-45.

— 1907. The Rate of Interest. New York. MacMillan.

— 1906. The nature of capital and income. New York; London: The Macmillan Company; Macmillan \& Co., ltd.

- 1896. Appreciation and interest. Publications of the American Economic Association 11 (4) (Jul.): pp. 1-98.

—. 1894. The mechanics of bimetallism. The Economic Journal 4 (15) (Sep.): pp. 527-537.

Fisher, Irving, Hans R. L. Cohrssen, and Herbert Wescott Fisher. 1933. Stamp scrip. New York: Adelphi Company.

Fisher, Irving, and Herbert Wescott Fisher. 1934. Mastering the crisis, with additional chapters on stamp scrip. London: G. Allen \& Unwin ltd.

Fisher, Irving, Eugene Lyman Fisk, and Life Extension Institute. 1922. How to live; rules for healthful living based on modern science, authorized by and prepared in collaboration with the hygiene reference board of the life extension institute, inc. 16th , rev ed. New York, London: Funk \& Wagnalls company.

Friedman, Milton. 2006. The Optimium Quantity of Money: With a new introduction by Michael D. Bordo. New Brunswick: Aldine Transaction

Friedman, Milton. 2004. Reflections on A monetary history. Cato Journal 23 (3) (Winter): 34951. 
-1992. Money mischief : Episodes in monetary history. 1st ed. New York: Harcourt Brace Jovanovich.

—. 1991. Monetarist Economics. Institute of Economic Affairs. Oxford: Basil Blackwell.

. 1990. Bimetallism revisited. The Journal of Economic Perspectives 4 (4) (Autumn): pp. 85-104.

. 1990. The crime of 1873. The Journal of Political Economy 98 (6) (Dec.): pp. 11591194.

. 1988. Money and the stock market. The Journal of Political Economy 96 (2) (Apr.): pp. 221-245.

—. 1982. Monetary Policy :Theory and Practice. Journal of Money, Credit and Banking. Vol 14, No.1 ( Feb), pp 98-118.

-1975. Unemployment versus inflation -- an evaluation of the Phillips curve. IEA Occasional paper no.44 Reprinted in Milton Friedman, Monetarist Economics London Institute of Economic Affairs. 1991.

. 1974. Monetary Correction, IEA Occasional Paper No.41. Reprinted in Monetarist Economics, Institute of Economic Affairs Oxford Basil Blackwell 1991.

. 1972. Have monetary policies failed? The American Economic Review 62 (1/2) (Mar. 1): pp. 11-18.

_.1970a. A theoretical framework for monetary analysis. The Journal of Political Economy 78 (6) (Nov. - Dec.): pp. 1385-1386.

-1970b. The Counter-Revolution in Monetary Theory. Institute of Economic Affairs. Occasional Paper 33. London.

- 1969. The optimum quantity of money, and other essays. Chicago: Aldine Pub. Co.

. 1968a. The role of monetary policy. The American Economic Review 58 (1) (Mar.): pp. $1-17$.

— 1968b. The Monetary Studies of the National Bureau in Milton Friedman ,The Optimum Quantity of Money and other Essays. Chicago :Aldine

- 1962a. The interpolation of time series by related series. Journal of the American Statistical Association 57 (300) (Dec.): pp. 729-757.

. 1962b. Capitalism and freedom. Chicago: University of Chicago Press. 
. 1960. A program for monetary stability. The Millar lectures. Vol. 3. New York:

Fordham University Press.

- 1957. A Theory of the Consumption Function. Princeton; Princeton University Press.

- 1956. The quantity theory of money - a restatement, In Studies in the quantity theory of money. Economics research studies of the economics research center of the university of Chicago. Chicago: University of Chicago Press.

. 1953; 1964. Essays in positive economics. Chicago ; London: University of Chicago Press.

- 1948. A Monetary and Fiscal Framework for Economic Stability American Economic Review ,Vol 38.No.3 ( June ) pp 245-264. reprinted in Essays in Positive Economics. Chicago: University of Chicago Press

Friedman, Milton, and L. J. Savage. 1948. The utility analysis of choices involving risk. The Journal of Political Economy 56 (4) (Aug.): pp. 279-304.

-1952. The expected-utility hypothesis and the measurability of utility. The Journal of Political Economy 60 (6) (Dec.): pp. 463-474.

Friedman, Milton, and Anna Jacobson Schwartz. 1982. Monetary trends in the United States and the United Kingdom, their relation to income, prices, and interest rates, 1867-1975. A national bureau of economic research monograph. Chicago: University of Chicago Press.

1970. Monetary statistics of the United States: Estimates, sources, methods. National bureau of economic research. studies in business cycles. Vol. 20. New York: National Bureau of Economic Research.

1964. Monetary studies of the national bureau. In The optimum quantity of money and other essays. Chicago: Aldine.

1963a. Money and business cycles. The Review of Economics and Statistics 45 (1, Part 2, Supplement) (Feb.): pp. 32-64.

. 1963b. A monetary history of the United States, 1867-1960. National bureau of economic research. studies in business cycles. Vol. 12. Princeton: Princeton University Press.

Hall, Robert E. 1997. Irving Fisher's self-stabilizing money. The American Economic Review 87 (2, Papers and Proceedings of the Hundred and Fourth Annual Meeting of the American Economic Association) (May): pp. 436-438. 
Haas, Jacob de. 1889. A third element in the rate of interest. Journal of the Royal Statistical Society 52 (1) (Mar.): pp. 99-116.

Hetzel, Robert L. 1985. The rules versus discretion debate over monetary policy in the 1920s. Federal Reserve Bank of Richmond Economic Review 71 (6) (November): 3-14.

Kemmerer, E. W., Duncan A. Mac Gibbon, Hugo Bilgram, L. D. H. Weld, B. M. Anderson Jr., and Irving Fisher. 1918. Money and prices--discussion. The American Economic Review 8 (1, Supplement, Papers and Proceedings of the Thirtieth Annual Meeting of the American Economic Association) (Mar.): pp. 259-270.

Keynes, John Maynard. 1936. The general theory of employment, interest and money. London: Macmillan and co., limited.

- 1930. A treatise on money, ed. Reprinted in 1971, Royal Economic Society. New York: Harcourt, Brace and Company.

Laidler, David. 1993. Hawtrey, Harvard, and the origins of the Chicago tradition. The Journal of Political Economy 101 (6) (Dec.): pp. 1068-1103.

1991. The golden age of the quantity theory. Princeton, N.J.: Princeton University Press.

Mints, Lloyd W. 1950. Monetary policy for a competitive society. 1st ed. New York: McGrawHill.

1945. A history of banking theory in Great Britain and the United States. Chicago, Ill.: University of Chicago Press.

Nelson, Edward. 2007. Milton Friedman and U.S. monetary history: 1961-2006. Federal Reserve Bank of St. Louis Review 89 (3) (May): 153-82.

Patinkin, Don. 1993. Irving Fisher and his compensated dollar plan. Federal Reserve Bank of Richmond Economic Quarterly 79 (3) (Summer): 1-33.

- 1969. The Chicago tradition, the quantity theory, and Friedman. Journal of Money, Credit and Banking 1 (1) (Feb.): pp. 46-70.

Phillips, A. W. 1958. The relation between unemployment and the rate of change of money wage rates in the United Kingdom, 1861-1957. Economica 25 (100) (Nov.): pp. 283-299.

Samuelson, Paul A., and Robert M. Solow. 1960. Analytical aspects of anti-inflation policy. The American Economic Review 50 (2, Papers and Proceedings of the Seventy-second Annual Meeting of the American Economic Association) (May): pp. 177-194. 
Simons, Henry C. 1945. The Beveridge program: An unsympathetic interpretation. The Journal of Political Economy 53 (3) (Sep.): pp. 212-233.

1936. Rules versus authorities in monetary policy. The Journal of Political Economy 44 (1) (Feb.): pp. 1-30.

Snyder, Carl. 1934. On the statistical relation of trade, credit, and prices. Review of International Statistical Institute.

Steindl, Frank G. 1995. Monetary interpretations of the great depression. Ann Arbor: University of Michigan Press.

United States. Congress. House. Committee on Banking and Currency, Irving Fisher, James Harvey Rogers, Robert D. Kent, Philip P. Wells, Frederick Leslie Ransome, Frank Alfred Wolff, George H. Shibley, William C. Lee, and Willford Isbell King. 1923. Stabilization of purchasing power of money: Hearings before the committee on banking and currency of the house of representatives, sixty-seventh congress, fourth session, on H.R. 11788 to stabilize the purchasing power of money. Washington: Govt. print. off.

Wicksell, Knut. 1907. The influence of the rate of interest on prices. The Economic Journal 17 (66) (Jun.): pp. 213-220. 
Table 1. Milton Friedman's References to the works of Irving Fisher

\begin{tabular}{|c|c|}
\hline Friedman & Reference to Fisher \\
\hline $\begin{array}{l}\text { The Spendings Tax as a Wartime Fiscal } \\
\text { Measure. AER vol.33, no. 1, part } 1 \\
\text { (March 1943): 50-62. }\end{array}$ & pp.61-62 [Constructive Income Taxation] \\
\hline $\begin{array}{l}\text { The Utility Analysis of Choices Involving } \\
\text { Risk. Milton Friedman and L. J. Savage. } \\
\text { The Journal of Political Economy. Vol. } \\
\text { 56, No. } 4 \text { (Aug., 1948), pp. 279-304 }\end{array}$ & $\begin{array}{l}\text { p. } 281 \text { [The indifference curve analysis of F.Y. } \\
\text { Edgeworth, Irving Fisher, and Vilfredo Pareto] }\end{array}$ \\
\hline $\begin{array}{l}\text { Wesley C. Mitchell as an Economic } \\
\text { Theorist. The Journal of Political } \\
\text { Economy Vol. 58, No. } 6 \text { (Dec., 1950), pp. } \\
465-493\end{array}$ & $\begin{array}{l}\text { p. } 470 \text { [Fisher's estimate of the amount of money held } \\
\text { by banks] }\end{array}$ \\
\hline $\begin{array}{l}\text { The Expected-Utility Hypothesis and the } \\
\text { Measurability of Utility. Milton Friedman, } \\
\text { L. J. Savage. The Journal of Political } \\
\text { Economy, Vol. 60, No. } 6 \text { (Dec., 1952), pp. } \\
\text { 463-474 }\end{array}$ & p.472 [Fisher's method of measuring utility] \\
\hline $\begin{array}{l}\text { Essays in Positive Economics, } 1953 . \\
\text { Chicago Press. }\end{array}$ & $\begin{array}{l}\text { p.42 [Fisher's quantity theory of money] Fisher is } \\
\text { cited along with Hume, the Cambridge School, and } \\
\text { Keynes as originators of major variants of the } \\
\text { quantity theory. }\end{array}$ \\
\hline $\begin{array}{l}\text { Leon Walras and His Economic System. } \\
\text { The American Economic Review, Vol. 45, } \\
\text { No. } 5 \text { (Dec., 1955), pp. 900-909 }\end{array}$ & $\begin{array}{l}\text { p.903 [Fisher's procedure for expressing the utility of } \\
\text { commodities] }\end{array}$ \\
\hline
\end{tabular}




\begin{tabular}{|c|c|}
\hline $\begin{array}{l}\text { Friedman, Milton. 1956. Studies in the } \\
\text { Quantity Theory of money. Economics } \\
\text { research studies of the economics research } \\
\text { center of the University of Chicago. } \\
\text { Chicago: University of Chicago Press. }\end{array}$ & $\begin{array}{l}\text { There is nothing on Fisher in Milton Friedman's } \\
\text { chapter but he is cited in Selden's chapter on velocity. }\end{array}$ \\
\hline $\begin{array}{l}\text { A theory of the consumption function, } \\
\text { NBER, Princeton University Press } 1957\end{array}$ & $\begin{array}{l}\text { p.7 [The Rate of Interest, ch.VI p.87-116; the Theory } \\
\text { of Interest, chs. X and XI] }\end{array}$ \\
\hline $\begin{array}{l}\text { The Demand for Money: Some } \\
\text { Theoretical and Empirical Results. The } \\
\text { Journal of Political Economy, Vol. 67, } \\
\text { No. } 4 \text { (Aug., 1959), pp. 327-351 }\end{array}$ & $\begin{array}{l}\text { p.348 [Fisher's argument in the Purchasing Power of } \\
\text { Money that improvements in transportation and } \\
\text { communication would produce a secular rise in } \\
\text { velocity.] }\end{array}$ \\
\hline $\begin{array}{l}\text { Money and Business Cycles. Milton } \\
\text { Friedman, Anna J. Schwartz. The Review } \\
\text { of Economics and Statistics, Vol. 45, No. } \\
\text { 1, Part 2, Supplement (Feb., 1963), pp. 32- } \\
64\end{array}$ & $\begin{array}{l}\text { p. } 32 \text { [The Business Cycle largely a Dance of the } \\
\text { Dollar] }\end{array}$ \\
\hline $\begin{array}{l}\text { A monetary history of the United States, } \\
\text { Friedman and Schwarz, 1963, NBER, } \\
\text { Princeton University Press. }\end{array}$ & p.70 [Appreciation and Interest, p.38-45] \\
\hline " " & p. 292 [Annals, p. 151]; p. 413 [Annals, p. 151] \\
\hline$" \quad " 1$ & $\begin{array}{l}\text { p. } 410 \text { [Booms and Depressions, pp. 96, 106, 126- } \\
\text { 134, 148-152] }\end{array}$ \\
\hline $\begin{array}{l}\text { The Monetary Studies of the National } \\
\text { Bureau, Milton Friedman and Anna J. } \\
\text { Schwartz, in The National Bureau Enters } \\
\text { its 45th Year, 44th Annual Report, 1964, } \\
\text { pp. 7-25. Reprinted in the Optimum } \\
\text { Quantity of Money and other Essays, } \\
\text { 1969, Milton Friedman. Chicago, Aldine } \\
\text { Publishing Company, 1969. }\end{array}$ & $\begin{array}{l}\text { p. } 265 \text { (reprint version) [The Business Cycle Largely } \\
\text { a 'Dance of the Dollar']. }\end{array}$ \\
\hline
\end{tabular}




\begin{tabular}{|c|c|}
\hline $\begin{array}{l}\text { Interest Rates and the Demand for Money. } \\
\text { Journal of Law and Economics, vol. 9, } \\
\text { October, 1966. Reprinted in the Optimum } \\
\text { Quantity of Money and other Essays, } \\
\text { 1969, Milton Friedman. Chicago, Aldine } \\
\text { Publishing Company, 1969, 141-55. }\end{array}$ & $\begin{array}{l}\text { p. } 152 \text { [Refers to Pigou and Fisher as quantity } \\
\text { theorists who recognized that interest rates affect } \\
\text { velocity. Specific reference to Pigou but none to } \\
\text { Fisher.] }\end{array}$ \\
\hline $\begin{array}{l}\text { The Role of Monetary Policy. The } \\
\text { American Economic Review, Vol. 58, No. } \\
1 \text { (Mar., 1968), pp. 1-17 }\end{array}$ & $\begin{array}{l}\text { pp.6-7. [Fisher's distinction between real and nominal } \\
\text { interest rates and Fisher's estimate that it took several } \\
\text { decades for full adjustment to inflationary } \\
\text { expectations.] }\end{array}$ \\
\hline $\begin{array}{l}\text { Post-war Trends in Monetary Theory and } \\
\text { Policy. National Banking Review, vol. 2, } \\
\text { no. } 1 \text { (September 1964). Reprinted in the } \\
\text { Optimum Quantity of Money and other } \\
\text { Essays, 1969, Milton Friedman. Chicago, } \\
\text { Aldine Publishing Company, 1969, 69-93. }\end{array}$ & $\begin{array}{l}\text { p.73 [Fisher's approach with its emphasis on } \\
\text { transactions and money as a medium of exchange is } \\
\text { contrasted with Keynes's emphasis of money as a } \\
\text { capital asset]; p.152 [refers to Fisher as one of the } \\
\text { researchers who was aware of the effect of interest } \\
\text { rates on velocity] }\end{array}$ \\
\hline $\begin{array}{l}\text { The optimum quantity of money, in the } \\
\text { Optimum Quantity of Money and other } \\
\text { Essays, 1969, Milton Friedman. Chicago, } \\
\text { Aldine Publishing Company, 1969, 1-50. }\end{array}$ & p.136 [Purchasing Power, pp.79-88] \\
\hline " " " & p.189, p.265 [Dance of the Dollar] \\
\hline $\begin{array}{l}\text { A Theoretical Framework for Monetary } \\
\text { Analysis. The Journal of Political } \\
\text { Economy, Vol. 78, No. } 2 \text { (Mar. - Apr., } \\
\text { 1970), pp. 193-238 }\end{array}$ & $\begin{array}{l}\text { p.196 [Purchasing Power, pp. 24-54]; p.198 } \\
\text { [Purchasing Power, pp. 280-318] }\end{array}$ \\
\hline " " " & p.198 [Money, Prices, Credit, and Banking] \\
\hline
\end{tabular}




\begin{tabular}{|c|c|}
\hline $\begin{array}{l}\text { Monetary Statistics of the United States: } \\
\text { Estimates, Sources, Methods. Milton } \\
\text { Friedman and Anna Jacobson Schwartz. } \\
\text { Published in } 1970 \text { by NBER, in NBER } \\
\text { Book Series Studies in Business Cycles }\end{array}$ & $\begin{array}{l}\text { p.202, p.260 , p.264-267, p.270, p.275 [Fisher's } \\
\text { estimates of currency held by the public] }\end{array}$ \\
\hline " " & $\begin{array}{l}\text { p.98 [ Purchasing Power, p.53-54], p.262 } \\
\text { [Purchasing Power, p.432, p.435], p.265 [ Purchaisng } \\
\text { Power, pp.440-441, pp. 436-437] }\end{array}$ \\
\hline $\begin{array}{l}\text { Monetarist Economics. Institute of } \\
\text { Economic Affairs Oxford Basil Blackwell } \\
\text { 1991, chapter } 1 \text { The Counter Revolution } \\
\text { in Monetary Theory' ( IEA Occasional } \\
\text { paper No.3. 1970) }\end{array}$ & pp.1,3,4 [Purchasing Power ] \\
\hline $\begin{array}{l}\text { A Monetary Theory of Nominal Income. } \\
\text { The Journal of Political Economy, Vol. } \\
\text { 79, No. } 2 \text { (Mar. - Apr., 1971), pp. 323-337 }\end{array}$ & $\begin{array}{l}\text { p.326, p.329, p.334, p.336 [References to Fisher's } \\
\text { distinction between the nominal and real rate of } \\
\text { interest] }\end{array}$ \\
\hline $\begin{array}{l}\text { Have Monetary Policies Failed? The } \\
\text { American Economic Review, Vol. 62, No. } \\
\text { 1/2 (Mar. 1, 1972), pp. 11-18 }\end{array}$ & p.11-12 [Recent Changes in Price Levels] \\
\hline $\begin{array}{l}\text { Comments on the Critics. The Journal of } \\
\text { Political Economy, Vol. 80, No. } 5 \text { (Sep. - } \\
\text { Oct., 1972), pp. 906-950 }\end{array}$ & $\begin{array}{l}\text { p.933-935, p. } 937 \text { [Fisher's use of the assumption that } \\
\text { prices adjust more rapidly than quantities]; p.934 } \\
\text { [Purchasing Power, pp.62-63]; p. } 935 \text { [Fisher's } \\
\text { distinction between nominal and real interest rates]; } \\
\text { p.947 [Fisher's version of the quantity theory]. These } \\
\text { references arose in Friedman's response to criticisms } \\
\text { by Don Patinkin that Friedman had misinterpreted } \\
\text { Fisher and other early proponents of the quantity } \\
\text { theory. }\end{array}$ \\
\hline $\begin{array}{l}\text { Monetary Correction, IEA Occasional } \\
\text { Paper No.41 1974. Reprinted in } \\
\text { Monetarist Economics, Institute of } \\
\text { Economic Affairs Oxford Basil Blackwell } \\
1991 .\end{array}$ & $\begin{array}{l}\text { p. } 25 \text { [refers to Fisher's support for a tabular } \\
\text { standard]. }\end{array}$ \\
\hline
\end{tabular}




\begin{tabular}{|c|c|}
\hline $\begin{array}{l}\text { Inflation, Taxation, Indexation IEA } \\
\text { Readings No.14, Inflation: Causes, } \\
\text { Consequences, Cures. 1974. Reprinted in } \\
\text { Monetarist Economics, Institute of } \\
\text { Economic Affairs Oxford Basil Blackwell } \\
1991 .\end{array}$ & p. 117 [refers to Fisher as favoring indexation] \\
\hline $\begin{array}{l}\text { Unemployment Versus Inflation? - An } \\
\text { Evaluation of the Phillips Curve, IEA } \\
\text { Occasional paper No.44 1975. Reprinted } \\
\text { in Monetarist Economics Institute of } \\
\text { Economic Affairs Oxford Basil Blackwell } \\
1991 .\end{array}$ & $\begin{array}{l}\text { pp. 63-65,67,70,71 [refers to Fisher } 1926 \text { ILO } \\
\text { article] }\end{array}$ \\
\hline $\begin{array}{l}\text { Discussion. The American Economic } \\
\text { Review, Vol. 65, No. 2, Papers and } \\
\text { Proceedings of the Eighty-seventh Annual } \\
\text { Meeting of the American Economic } \\
\text { Association (May, 1975), pp. 176-181 }\end{array}$ & $\begin{array}{l}\text { p.177 [Fisher's view on the formation of inflationary } \\
\text { expectations and public policy] }\end{array}$ \\
\hline $\begin{array}{l}\text { Nobel Lecture: Inflation and } \\
\text { Unemployment. The Journal of Political } \\
\text { Economy, Vol. 85, No. } 3 \text { (Jun., 1977), pp. } \\
451-472\end{array}$ & No Reference to Fisher \\
\hline $\begin{array}{l}\text { Monetary Trends in the United States and } \\
\text { the United Kingdom, Friedman and } \\
\text { Schwarz, 1982, NBER, The University of } \\
\text { Chicago Press }\end{array}$ & $\begin{array}{l}\text { p.11 [Fisher's view on relation between interest rates } \\
\text { and the anticipated rate of price change], p.44 } \\
\text { [Fisher's view of the transition period], p.275 } \\
\text { [Fisher's view that anticipated nominal yield can be } \\
\text { regarded as the sum of an anticipated real yield and } \\
\text { an anticipated rate of change of prices], p.477,p.490 } \\
\text { [Fisher's distinction between nominal and real } \\
\text { interest rates; Fisher on the formation of inflationary } \\
\text { expectation], p.497-499 [Fisher's explanation of } \\
\text { Gibson paradox; Fisher's view on real disturbances], } \\
\text { p.568 [Fisher's expectations hypothesis] }\end{array}$ \\
\hline " " & $\begin{array}{l}\text { p.478, p.517-518 [Rate of Interest, p.286], p.522 } \\
\text { [Rate of Interest, p.279-80], p.546-547 [Rate of } \\
\text { Interest, p.284-85] }\end{array}$ \\
\hline " & $\begin{array}{l}\text { p.19 [Purchasing Power, pp.24-54], p.22 [Purchasing } \\
\text { Power, pp.280-318] }\end{array}$ \\
\hline & p.22 [Money, Prices, Credit, pp.407-409] \\
\hline
\end{tabular}




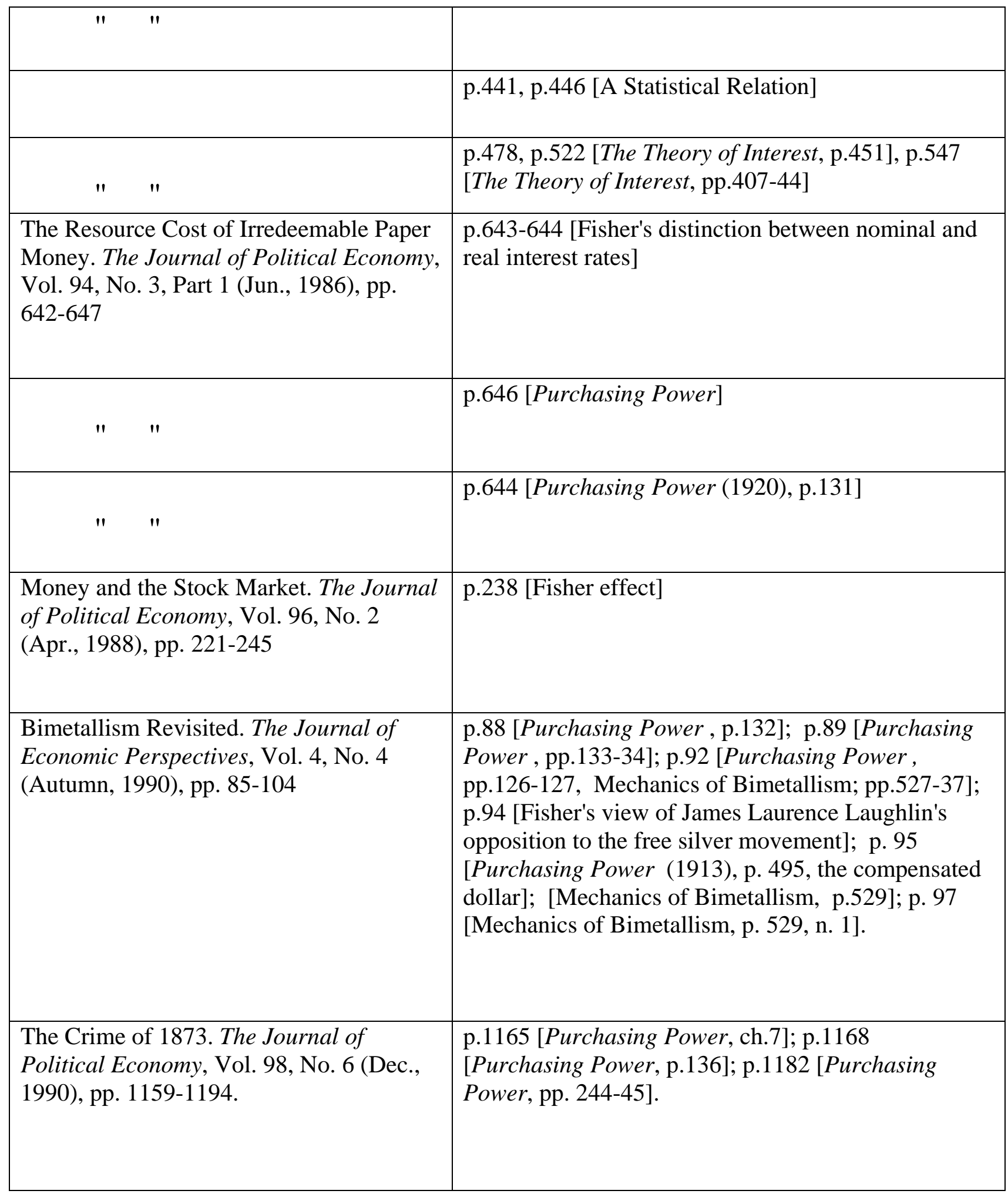




\begin{tabular}{|l|l|}
\hline $\begin{array}{l}\text { Old Wine in New Bottles. The Economic } \\
\text { Journal, Vol. 101, No. } 404 \text { (Jan., 1991), } \\
\text { pp. 33-40 }\end{array}$ & $\begin{array}{l}\text { p.35 [As an amusing aside, of the } 70 \text { pages with } \\
\text { mathematical symbols in the first 10 volumes of the } \\
\text { JOURNAL (out of over 7,000), ..., } 10 \text { by Irving } \\
\text { Fisher,... }\end{array}$ \\
\hline $\begin{array}{l}\text { Note. The right hand column shows the page reference in Friedman and in brackets the reference } \\
\text { to Fisher. The reference to Fisher may be a general reference to Fisher's idea (for example the } \\
\text { Fisher Effect), a reference to a specific publication, or a reference to a specific publication with a } \\
\text { page number. }\end{array}$
\end{tabular}

